\author{
EMILIA WĄSIKIEWICZ-FIRLEJ \\ Uniwersytet im. Adama Mickiewicza w Poznaniu
}

\title{
Language and education policy as one of the main challenges of migrant integration in Poland
}

\begin{abstract}
This article aims to map current state policy and governmental responses to migrant integration in Poland, as well as to identify pressing needs and key challenges in this area, with a particular focus on language and education. It draws on a literature review and analysis of legal documents and reports on migrant integration and language policy for 1989-2020. When analysing the data, particular attention was paid to the declared state policy on migrant integration and its actual implementation, as captured in the Supreme Audit Office (NIK 2015, 2020) and Migrant Integration Policy Index reports (MIPEX 2015, 2020). The research shows that the scope of integration activities and their effects have been unsatisfactory to date. The situation of migrants in Poland was dubbed "equality on paper" in the MIPEX 2020 report. Current programmes and activities are not fostering full integration of migrants. Apart from housing and employment issues, a lack of language skills and education that is not responsive to the needs of migrants remain the main barriers to migrant integration in Poland.
\end{abstract}

KEYWORDS: migrant integration, language policy, migration policy, language and education.

\section{INTRODUCTION}

The article examines migrant integration strategies adopted by policymakers in Poland as a relatively new destination for newcomers and seeks to acknowledge the existing policies and adopted models of migrant integration in Poland with a special focus on language and education. The main premise underlying this paper is that Poland has inconsistent integration policies, which pose significant challenges to migrants, negatively affecting their daily functioning and hindering their integration and participation in social life. Therefore, the main rationale for the current analysis is the lack of updated accounts on the status quo migrant integration in Poland available in the English language that could contribute to the relevant discussion and exchange of experiences in a wider context. Thus, the paper aims to identify current state policies and governments' responses to migrant integration as well as discern burning needs and key challenges in this area. 
As far as the research data is concerned, the article draws on a literature review as well as the analysis of legal documents and reports for the period 1989-2020. When analysing the data, special attention was paid to the state declarative migrant integration policy and its real-life realisation as outlined in MIPEX 2015 and 2020 reports (MIPEX 2015, 2020). Additionally, by comparing the findings and recommendations of the two reports, the progress and developments in migrant integration policy are assessed. Finally, in a broader sense, the paper also attempts to contribute to a better understanding of migrant integration processes with the ultimate goal to minimise the marginalisation of migrants and foster their integration in contemporary Poland.

The article is organised in the following way. It begins with an overview of migrant integration policies in Poland to provide the context for a discussion in the next sections centred on language and education policies (Sections 3 and 4, respectively). Based on the analysis of 2015 and 2020 MIPEX, as well as the Supreme Audit Office [Pl. Najwyższa Izba Kontroli (NIK); hereinafter SAO] reports, Section 5 overviews the challenges to migrant integration in Poland. The final section provides the conclusions to the literature review and document analysis undertaken. The findings of the analysis will partly contribute to the intellectual outputs developed in the MaMLiSE Project - Majority and Minority Languages in School Environment: Helping Teachers, Pupils and Parents, 2020-1-PL01-KA201-081612, funded by the European Commission under the Erasmus+ program, KA201-Strategic Partnership for school education.

\section{MIGRANT INTEGRATION POLICIES IN POLAND}

Before Poland's accession to the UE in 2004, the scale of migration to Poland was marginal so until the last decade, the issue of migrant integration was not given much attention (Lesińska 2010: 102-103). The studies comparing integration practices in Poland with the experiences of Western countries generally indicated provisional, chaotic actions in various areas of integration policy (Łodzinski \& Grzymała-Kazłowska 2011). In recent years, however, there has been a significant increase in interest in this area, inspired mainly by EU funds allotted for research and activities for the integration of migrants (Lesinska 2010: 108). Like other new Member States, Poland has adopted EU practices on migration and integration but failed to tailor them to national needs and specificities (Pawlak 2013: 97-121). In Poland, various aspects of foreigners' integration have been regulated in many legal acts, referring mainly to Polish citizens. These are, for example, the Act on Social Assistance of 2004, the Act on the Education System of 1991, the 2004 Act on Health Care Services 
financed with public funds or the 1998 Act on the Social Insurance System (cf. Rajca 2015: 191).

Although the Government has made certain efforts to draft some documents defining the policy of migration and integration of foreigners in Poland, attempts to formulate a comprehensive state migration policy have so far been unsuccessful. According to experts from the Department of Analysis and Migration Policy of the Ministry of Interior and Administration (Polityka migracyjna Polski... 2020: 3), the only attempts that can be considered partially successful are the development of the document "Migration policy of Poland - the current state and postulated actions", adopted by the Council of Ministers in 2012 and cancelled in 2016, and the document "Socio-economic priorities of the migration policy", developed under the guidance of the Ministry of Investment and Development and adopted by the Council of Ministers in 2018. However, there is no document that comprehensively and coherently addresses the issue of coordination of state actions towards migration processes. The inability to foresee the dynamics of changes in the migration situation in Poland and the migration situation in Europe resulted in the rapid outdating of the document "Migration policy of Poland - the current state and postulated actions" (Polityka migracyjna Polski... 2012). Based on this assumption, current activities aimed at developing the migration policy of the country are based on the conviction that both the migration processes and the migration situation of the country are subject to constant transformations and changes which may occur. Therefore, the migration policy should be updated on an annual basis as well as, if necessary, in response to unexpected changes in the situation.

In 2020, work on the new migration policy of the country was commenced, changing the method of proceeding used in previous schemes, which was enforced by the need to render the changeability of the situation. A set of main assumptions and lines of action for 2021 was established, together with a timetable, which allowed the development of a diagnosis based on the current migration situation. Unfortunately, the Covid-19 epidemic halted progress, making it impossible to implement the previously adopted schedule. Despite certain organisational limitations and difficulties with updating elaborated analyses and obtaining new necessary materials, the works continued and the Migration Team managed to resume activities important for the implementation of the set objective undertaken during the pandemic (Polityka migracyjna Polski... 2020: 3).

Regardless of the future development of the pandemic, issues related to migration processes require planned and coordinated activities. It was therefore decided to develop a diagnostic document and lines of action for 2021, as further delay in starting the process of preparing a migration policy would endanger the process itself. The development of a set of basic principles has been postponed to 
a further time horizon. In subsequent periods, the preparation of new diagnostic material and directions of action for subsequent years will create an opportunity to fill in gaps and improve the very form of these documents. The representatives of the Polish administration are members of the EU Council working groups and European Commission committees. In the groups and committees draft legal acts and strategic documents of the Union are prepared, also concerning migration. An annually updated document on migration policy will take into account the changes introduced to the law and practice of the state in the field of migration. From this point of view, the new "Pact on Migration and Asylum" will be of particular importance for the migration policy of the country (Polityka migracyjna Polski... 2020:3).

The integration programmes implemented so far have been addressed mainly to refugees and repatriates. Integration of foreigners under international protection is a two-stage process. The realisation of the first stage lies with the responsibility of the Office for Foreigners and includes the period of waiting for the granting of refugee status (pre-integration) in centres for refugees (Rajca 2015: 192). As research shows, the stay in these centres is not conducive to integration within society (Łodzinski \& Ząbek 2010: 236). The second type of integration, i.e. actual integration, concerns persons who have obtained refugee status or have been granted subsidiary protection. They have the right to apply to the starost [district governor] with jurisdiction over the foreigner's place of residence for an individual integration programme (IIP). It is implemented by the district family assistance centres and supervised by the Minister of Family, Labour and Social Policy. Assistance under the IIP depends - at least in theory - on active participation in the integration programme and the fulfilment of obligations related to the integration contract. In 2012-2014, 674 IIPs covering 1459 people were implemented in 51 counties (NIK 2015). It is difficult to unequivocally assess the effects of integration activities, as the legal provisions do not require monitoring the situation of foreigners after the completion of the individual integration programme. The 2015 report of the Supreme Audit Office shows that IIPs were most often only of a formal nature, and their development was aimed at fulfilling statutory requirements (NIK 2015). Monetary benefits were the main element of the IIP. The obligation arising from the Act on Social Assistance to learn the Polish language during the implementation of the IIP was carried out almost exclusively by non-governmental organisations, which play a substantial role in migrant integration. However, the activities undertaken to learn the Polish language have not ensured the possibility of mastering it to an extent that would allow individuals to function in the local labour market (Rajca 2015: 193).

The current legal provisions in Poland do not prescribe any special treatment for refugees on the labour market, even though employment has a major impact 
on other dimensions of integration. Only very few refugees have found work or obtained permanent residence. It is therefore not surprising that there is little progress in the area of social functioning, the achievement of which is made even more difficult by the unwelcoming attitude of society and the authorities. The schools audited by the Supreme Audit Office, which were attended by children of foreigners, in most cases did not offer support for these pupils in the ways provided for in the Act on the Educational System, i.e. offering additional free Polish language learning or additional remedial classes. As reported by the Supreme Audit Office, the current system of social assistance for refugees discourages them from staying in Poland rather than fosters their integration into society and taking up independent life (NIK 2015). The literature stresses that the integration of refugees is impeded by the lack of housing, stable well-paid work and language skills, as well as low education and professional qualifications of refugees (Łodzinski \& Grzymała-Kazłowska 2011: 30).

The second group that is entitled to integration assistance is that of the repatriates. Studies indicate significant adaptation and integration problems of this group of people (Hut 2002). In the Act of 9 November 2000 on repatriation, the types of assistance provided to repatriates are specified. Imposing on local authorities the obligation to undertake integration efforts (guarantee of housing and assistance in finding a job) proved to be an obstacle hindering the repatriation process (Rajca 2015: 193-194). Criticism of the poor results of repatriation programmes prompted the drafting of a civic repatriation law in 2010. Additionally, the Supreme Audit Office, in its post-audit statement of 2014, negatively assessed the implementation of migration policy concerning foreigners declaring Polish origin. It pointed out, among others, the following: no concept of a comprehensive system of care for repatriates; no concept of assistance and motivational system for repatriates intending to find places of settlement on their own; no analysis of the need for activities in the field of professional activation among repatriates; no data enabling the management (monitoring) of the implementation of tasks resulting from the Government Programme of Cooperation with Poles and Poles Abroad (Kutyła 2014).

The critical voices finally paved the path to the updating of the repatriation law in 2017. Under the new law, the repatriate status has been extended to persons living in the Asian part of the former USSR. The Act of 7 April 2017 enables opening asylums for repatriates which provide Polish language courses as well as ensuring housing benefits to repatriates.

With regard to foreigners who are not beneficiaries of international protection, Poland has not conducted any active integration activities so far - except for co-financing projects implemented since 2007 under the European Fund for the Integration of Third-Country Nationals. As noted by Rajca (2015: 194), 
these projects implemented mainly by non-governmental organisations (NGOs) (e.g. legal and vocational counselling, educational projects, including language courses, cultural projects), often in public-private partnerships, were aimed both at third-country nationals and the receiving society (two-way integration). A detailed analysis by Matusz-Protasiewicz shows that it is very difficult to assess the effectiveness of these integration activities (Matusz-Protasiewicz 2014: 86 et seq.) This results from a lack of data that would allow us to state how these activities have translated into tangible integration effects and to assess unequivocally whether non-governmental organisations have become effective in integration activities or only efficient in obtaining available funds (cf. Rajca 2015: 195).

In the current state of the law, integration policy does not belong to the tasks of local governments. Local actions have an ad hoc rather than systemic character, based on the goodwill of local government representatives and their voluntary cooperation with other entities, especially with NGOs. Apart from the largest cities, only a few local governments undertake any activities exceeding their statutory competence (Open Cities). Some cities (Warsaw, Lublin, Wrocław), using EU funds, have taken the first actions in the field of diversity management (Matusz-Protasiewicz 2014). They do not stem from challenges, but more from the availability of European money and trends towards multiculturalism (Rajca 2015: 196).

\section{LANGUAGE POLICY IN POLAND}

The Polish language has the status of the only official language in Poland. The highest legal act regulating language policy in Poland is the current Constitution, enacted and implemented in 1997, which explicitly states in Article 27 that: "[i]n the Republic of Poland the Polish language shall be the official language. This provision does not affect the rights of national minorities under ratified international agreements" (Konstytucja RP). This document refers to the issue of language in two more instances. Namely, Article 45, paragraph 1, indicates that "the Republic of Poland guarantees Polish citizens belonging to national and ethnic minorities the freedom to maintain and develop their language, preserve their customs and traditions and develop their own culture" (Konstytucja RP). On the other hand, the Constitution (Article 233, paragraph 2) states that "It is inadmissible to restrict the freedoms and rights of a human being and citizen solely on the grounds of race, sex, language, religion or lack thereof, social origin, birth and property" (Konstytucja RP).

Another legal act relating to the national language is the Act on the Polish Language (Ustawa o języku polskim 2018), which was adopted on 7 October 
1999 and has subsequently been amended several times. This law was created upon the initiative of a group of Polish philologists, who perceived the globalisation processes and the prospect of Poland's accession to the EU as a potential threat to the national language. The document addresses the following issues: ensuring the accuracy of usage, counteracting vulgarisation, popularisation of Polish language abroad, supporting its teaching. Additionally, it has a goal of "promoting respect for regionalisms and dialects and preventing their disappearance" (Ustawa o języku polskim 2018, Chapter 1, Art. 3) and specifies the rules for the use of foreign languages and their impact on Polish in the area of culture and education as well as in business and legal transactions, etc. Non-compliance with the rules is threatened with the rigour of legal sanctions (Ustawa o języku polskim 2018, Chapter 4, Article 14). Under this document, the Council for the Polish Language was also established, which is to fulfil the function of an opiniongiving and advisory institution and to submit to the Polish Sejm and Senate, i.e. the lower and higher chamber of the Polish Parliament, at least every two years, a report on the state of protection of the Polish language (Ustawa o języku polskim 2018, Chapter 3, Article 12). It is worth noting at this point that the Act was not adopted unanimously and critical voices were raised. For example, it received criticism not only from legal circles (Mostowik \& Żukowski 2001), who accused it of inconsistencies in its provisions, mistakes and even harmfulness but also from linguists (Piotrowski, 2011), who reproached the document for its fictitious creation of a state of emergency and its prescriptive approach to language (cf. Wąsikiewicz-Firlej, Szczepaniak-Kozak \& Lankiewicz in press).

Even though Poland is quite homogenous linguistically and culturally compared to other European countries, several ethnic groups can be distinguished. Their list is published by the Central Statistical Office [Pl. Główny Urząd Statystyczny, GUS] based on the census, which last took place in 2011 (GUS 2011), and the Act on National and Ethnic Minorities and Regional Language (Ustawa o mniejszościach... 2017). However, it should be remembered that the concepts of declared and statutory minorities differ. In the statutory sense, only a group of people who have Polish citizenship and meet certain criteria together can be considered a national minority. One of them is that "their ancestors have inhabited the present territory of the Republic of Poland for at least 100 years" (Ustawa o mniejszościach... 2017, Chapter 1, Article 2). Hence, the said Act recognises as a minority only the Belarusian, Czech, Lithuanian, German, Armenian, Russian, Slovak, Ukrainian and Jewish communities. On the other hand, the Karaite, Lemko, Roma and Tatar communities are recognised as ethnic minorities. Even inclusion in the latter group requires the combined fulfilment of several conditions. What distinguishes a national minority from an ethnic minority is the fact that it "does not identify with the nation organised in its own state" (Ustawa 
o mniejszościach... 2017, Chapter 1, Article 2). The document recognises the linguistic distinctiveness of Kashubians by referring to the European Charter for Regional or Minority Languages, which came in force in Poland in 2009 (cf. Baranowska 2014), and defines the Kashubian language precisely as a regional language. Based on this law, the language of a national or ethnic minority may be used by the commune authorities, apart from the Polish language, if the number of minorities is not lower than $20 \%$ of the total population and, additionally, such a commune must be registered in the Official Register of Communes in which an auxiliary language is used" (Ustawa o mniejszościach... 2017, Chapter 1, Article 9). Attempts were made to extend this right to the district unit, but the President of Poland, Andrzej Duda, vetoed this amendment in 2015 (Prezydent.pl).

The rights of national minorities and ethnic groups living in Polish territory, including linguistic ones, are protected by European legislation and by Polish national legislation. They are guaranteed by the Constitution of the Republic of Poland, which stipulates in Article 35, paragraph 1, that "The Republic of Poland guarantees Polish citizens belonging to national and ethnic minorities the freedom to maintain and develop their language, preserve customs and traditions and develop their own culture", and additionally in paragraph 2 it ensures that "National and ethnic minorities have the right to establish their own educational, cultural and institutions for the protection of their religious identity and to participate in the settlement of matters concerning their cultural identity" (Konstytucja RP). These rights are further elaborated in the Act on Education System of 1991 (Ustawa o systemie oświaty... 1991), which obliges public schools in Poland to "enable pupils to retain their sense of national, ethnic, linguistic and religious identity, and in particular, shall make it possible for them to learn their own language, history and culture" (Ustawa of systemie oświaty... 1991; after Baranowska 2014: 41). Thus, at least on paper, legal protection of national and ethnic minorities is guaranteed and does not deviate from other European countries (Kirpsza 2012; Romanowski 2020). Another issue, however, is the execution of the rights provided by the legislator (Baranowska 2014: 48). The challenges faced by particular minorities are discussed in more detail by Romanowski (2020).

Until the fall of communism, in the then People's Republic of Poland, the problems of language policy mostly pertained to the accuracy of language use. This was the result of the country being considered homogeneous in terms of nationality by the communist authorities and suppression of any alternative voices by the prevailing censorship. On the other hand, some disputes relating to matters of language policy did take place (Pisarek 2007). The issues of language policy in our country regarding the languages of national minorities started with the adoption by Poland of the first European document on the pro- 
tection of minority rights, including language, the Framework Convention for the Protection of National Minorities (Konwencja ramowa... 1995). As Pisarek (2007) noted, the act of signing the Convention by Poland in 2001 landmarked a "shift of the national framework" in the Polish language policy "towards the civic framework". According to Pisarek (2007), this is particularly evident in the amendments to the Act on the Polish Language, introduced in 2004, from which "the spirit of a civil society whose full-fledged members are not only people of Polish nationality" shines through (Pisarek 2007).

As far as the practical dimension of the Convention is concerned, it is limited by the annexe (Interpretative Declaration), resulting from the political consensus of the member states of the Council of Europe, which is expressed by leaving the decision on the recognition of a given minority group to the signatory state. As pointed out by the Advisory Committee on the Framework Convention for the Protection of National Minorities (FCNM Opinion on Poland 2003, Chapter III, Article 3), Poland issued two declarations when it ratified the Framework Convention. The first of these declarations states the following: " $[\ldots]$ the Republic of Poland declares that it understands this term as national minorities residing within the territory of the Republic of Poland at the same time whose members are Polish citizens" (Pisarek 2007). The second declaration is specifically related to Article 18 and reads as follows: "The Republic of Poland shall also implement the Framework Convention under Article 18 of the Convention by the conclusion of international agreements mentioned in this Article, the aim of which is to protect national minorities in Poland and minorities or groups of Poles in other States" (Pisarek 2007). In the concluding remarks of the FCNM Opinion on Poland (2003), experts appreciated Poland's efforts to provide support for national minorities and their respective cultures but pointed simultaneously to certain legal incoherence and a range of shortcomings in the area of minority languages provision in the administrative, educational and media sectors. The recommendations also responded to the voiced demands of national minorities, especially those of Germans, Ukrainians and Jews, to solve problems related to monuments and cemeteries, and foster the establishment and maintenance of minority cultural centres, libraries and museums (FCNM Opinion on Poland 2003).

It can be assumed that Poland's accession to the EU resulted in intensified concern about the status of its language within this organisation. The aforementioned provisions of the EU law have contributed to the activities of the Polish authorities in promoting our language in the EU. Many of these activities take place through the European Federation of National Institutions for Languages (EFNIL), which was established in Stockholm in 2003 as a network of institutions from the European Union Member States dealing with language matters. The Council for the Polish Language has been a full member of EFNIL since 2006. 


\section{LANGUAGE EDUCATION IN POLAND}

Learning the Polish language is obligatory not only for members of national and ethnic minorities but also for communities speaking a regional language (e.g. Kashubian). Minorities are, however, offered a possibility to take part in their language classes and cultural activities. A minority language may be used as the language of instruction, the second language of instruction as it is the case in bilingual education, or as an optional subject. Minority language teaching can be organised for as few as seven pupils at the request of parents or in inter-school groups of 3-20 pupils in more dispersed groups (Poszytek et al. 2005; Romanowski 2020). The teaching of learning of minority languages in Poland is coordinated and funded by the state. In reality, the repertoire of minority languages offered as languages of instruction is limited to Lithuanian and Ukrainian. For example, the efforts of the German minority to introduce bilingual education have so far remained unsuccessful. Yet, regional or minority languages, such as Belarusian, Kashubian, Lemko, and Ukrainian, might be taught as school subjects (Romanowski 2020: 18).

Poland's language policy does not only involve taking care of the national language and protecting the languages of national and ethnic minorities. An integral part of it is also the educational policy concerning the learning of foreign languages. The promotion of language learning in Poland on a larger scale began after the fall of communism. Since 1999 the reform of the school system was launched in all sectors of education, with the aim of bringing it into line with European standards. During this period, the number of public and private higher education institutions increased considerably, and all types of foreign language teacher training and philological studies became immensely popular. Significant growth in the number of publications, conferences and studies related to foreign language teaching and learning has been also observed (cf. Komorowska 2017: 82ff).

An important element of the language learning process is the use of European documents, including the translation into Polish of the Common European Framework of Reference for Languages (2001) that took place two years after its first publication. After the changes in the core curriculum in 2007, since September 2008 learning a foreign language became compulsory from the first grade of primary school, and learning a second foreign language in lower secondary and secondary school classes. Despite certain objections raised by teachers of other foreign languages (Kucharczyk 2016), the dominance of English in Polish schools remains unshaken, as reflected in the latest census (Statistics Poland 2020: 135).

Currently, according to the core curriculum in force since 2017, learning a foreign language begins in kindergarten and continues throughout primary 
and secondary school. From the seventh grade of primary school, the learning of a second foreign language is introduced. As recommended, "it should become a principle to provide students with the opportunity to continue learning the same foreign language as their first language at all educational stages, from the first grade of primary school to the last grade of secondary school (i.e. for 12 or 13 years)" (Smolik \& Poszytek 2017: 70). The new system aims to ensure effective communication in spoken and written foreign languages at a specific CEFR level, according to the variant of the core curriculum. Taking into account that except for compulsory English most schools typically provide German or less frequently Russian or French as the second foreign language (Statistics Poland 2020), migrant children are often exposed to three new languages, i.e. Polish, English, and another foreign language that rarely coincides to be their heritage language (e.g. Ukrainian, Belarussian or Vietnamese). Additionally, the continuity of learning the second foreign language is not always ensured at higher levels of education which might potentially translate into learning another foreign language in secondary school (Komorowska 2017; Raport Eurydice 2017). Much as multilingualism is appreciated, in some cases, the simultaneous exposure to so many languages can be burdensome and pose additional challenges for children with a migrant background, especially during the initial adaptation to the new educational settings and the focus on mastering the majority language. In addition to the difficulties experienced, intensive learning of several foreign languages at the same time might occur at the expense of heritage language attrition, which seems to be unfavourable from the point of view of the use of personal resources.

\section{REMAINING CHALLENGES}

The magnitude of challenges and problems for Poland is signalled in the 2015 and 2020 Migrant Integration Policy Index report (MIPEX 2015, 2020) - a tool which uses 167 indicators to evaluate and compare government efforts to promote migrant integration in the EU member states and several other countries around the world. Eight areas of integration policies are periodically assessed, namely: labour market, family formation, education, health, political participation, right to permanent residence, right to obtain citizenship and protection from discrimination.

In the recent report (MIPEX 2020), the results obtained by Poland in the field of migrant integration policy were rather disappointing since only four countries in the EU scored lower (Croatia, Slovakia, Lithuania, and Latvia). Poland scored 40 out of a maximum of 100 points, which is below the whole European Union (EU28) average (49) but comparable to other new EU new member states 
(EU13). By contrast, among European countries, the highest-rated were Sweden (86), Finland (85), and Portugal (81), which along with Canada (80) and New Zealand (77), topped the world MIPEX 2020 ranking.

Poland's approach to integration policies has been categorised as slightly unfavourable and described "equality on paper" only, which "means that immigrants enjoy equal rights and long-term security, but not equal opportunities" (MIPEX 2020). Such policies create multiple barriers to the integration of non-EU citizens. Similarly to other Central and Eastern European countries, migrants in Poland benefit from some basic rights and security (e.g. to settle long-term), but are not afforded equal opportunities. These areas require improvement since, in comparison to most MIPEX countries, in Poland, equal rights and equal opportunities for migrants remain below average. In everyday life, migrants in Poland encounter the most severe difficulties in four areas that scored the lowest in MIPEX 2020, i.e. political participation (10), health (27), labour market mobility (31), and education (33).

An important aspect of integration is the participation of migrants in political life. Yet, in Poland the opportunities for migrants to participate in political life are limited. Polish law in this regard is among the most restrictive in Europe since only Polish citizens and citizens of the EU member states are entitled to vote and to be elected in local government elections, stand for community or town councillor and participate in referendums (cf. Rajca 2015: 195). The possibility of founding political parties and being their members is also restricted to Polish citizens (Polska polityka integracji cudzoziemców 2013: 23). Indeed, in MIPEX (2020) report political participation, qualified as unfavourable (score: 10), appears to be the weakest area across Central Europe. Under current policies, migrants in Poland are deprived of the right to vote, support or consultation by policymakers, which in practical terms excludes them from participation in public life.

Health services and policies, labelled slightly unfavourable (score: 27), is another area that generates obstacles to migrants and does not respond to their specific needs. The main obstacle is limited access to healthcare and insufficient target-oriented information on healthcare provisions. It must be noted, however, that compared to the previous ranking (MIPEX 2015), since 2014, certain positive changes might be observed in this field. With the launch of a new website for promoting health education, accessing the information on health education and promotion has been facilitated to migrants.

Labour market mobility appears to be another problematic, slightly unfavourable (score: 31), area. Although Poland has opened to labour migrants, which has made finding a job or starting a business activity easier, non-EU newcomers are still not offered the same benefits or general support as Polish or EU citizens to enhance their skills and careers. 
The remaining aspects of integration included in MIPEX (i.e. permanent residence, access to nationality, family reunification, anti-discrimination) obtained more favourable scores and represent at least the EU average. In MIPEX 2020 report, the permanent residence has been defined as halfway favourable (score: 50). Compared to previous years, nowadays migrants in Poland face greater uncertainty in their efforts to settle as permanent residents due to more restrictive economic and language requirements that were introduced in 2018. Under these requirements, applicants need to prove that they have a stable and regular source of income to provide for subsistence costs of themselves and their dependants, and are required to certify their knowledge of the Polish language at B1 level. It must be admitted, though, that permanent residents then enjoy a considerable degree of security and are entitled to equal access to social benefits.

Access to nationality has been also deemed halfway favourable (score: 50). Compared to other EU/OECD countries, the difficulty of the Polish path to citizenship is rather average. To become dual nationals, since 2012 migrants in Poland must meet a number of residential, linguistics and economic requirements. As far as family reunification is concerned, it has also been qualified as halfway favourable (score: 58) since the law in Poland to a certain degree fosters the process of non-EU families reunification and integration in society. Finally, anti-discrimination has obtained the highest score (63) and has been categorised as slightly favourable. On the one hand, the law and its enforcement guarantee equality to migrant residents in all areas of life. On the other hand, "victims are not only confronted with a young law still weak in a few areas, but they also receive less help in Poland than in most countries from its weak equality body and weak equality policies" (MIPEX 2020). This situation ideally renders the status quo of Poland's migration integration qualified in MIPEX 2020 as "equality on paper".

The latest MIPEX report has shown that Polish migrant integration policy still creates more barriers than opportunities for migrants to participate with full rights in society, in comparison with other Central European countries. Compared to the previous ranking (MIPEX 2015), certain slight improvements have been only made in the area of political participation, education and health but the overall result turned out to be minimally lower (-1). Poland's current policies do not foster public views of migrants as their equals, neighbours and potential citizens but instead perpetuate their perception as strangers. As summarised by MIPEX experts:

Restrictive policies like Poland's can create a 'vicious circle' of exclusion that reinforces fear and separation. Policies that treat immigrants as threats lead more people to see immigrants as general threats and treat them in ways that harm integration. Under restrictive policies, the public experiences higher levels of xenophobia and 
islamophobia and lower levels of social trust, which leads them to fewer contacts and positive experiences with immigrants. (MIPEX 2020)

The above quotation shows that Poles are filled with many fears and prejudices against migrants and are not sufficiently prepared for their inclusion in social life. This indicates that there is an urgent need for top-down and bottom-up integration and educational activities leading to increasing cultural awareness of Poles and changing their attitudes towards migration and acceptance of the growing cultural diversity and multilingualism.

In recent years, Poland has received a very large number of people of Ukrainian, Belarusian and Vietnamese nationalities in particular, who wish to settle permanently in Poland. Taking into account the number of foreign students enrolled in education in the Polish educational system that has increased in the last decade from 9,610 in 2009 to 51,363 in 2019, educational challenges are by no means marginal. The most numerous group in primary and secondary schools was made up of students from Ukraine (30,777 persons). Classes for foreign students were provided in the school year 2019/2020 in 7,318 schools, compared to 1,571 schools in the school year 2009/2010 (NIK 2020). Challenges in the education of children with a migration background (CMB) including children of Polish citizens returning from abroad, were highlighted by the Supreme Audit Office (SAO) in its recent report, which examined how this process progressed in the school years from 2017/18 to 2019/20 (NIK 2020). The audit targeted the Ministry of National Education and 24 public primary and secondary schools. In addition, the SAO conducted a questionnaire survey among teachers of the audited schools teaching CMBs.

On the one hand, the audit report (NIK 2020) showed that CMBs are provided with educational opportunities in Poland, including adequate conditions for learning the Polish language. Parents mostly positively evaluated the process of adaptation and integration of their children into the school environment. However, the SAO audit showed a complete lack of interest in this issue on the part of the Minister of National Education, who is responsible for educational policy. The Ministry does not monitor the situation nor perform relevant analyses, has practically no knowledge on the subject and has done nothing to obtain it. It turns out that teachers are a considerable asset, who, despite the institutional lack of support, are mostly committed to their work.

The Minister of National Education, who bears responsibility for the coordination and implementation of the state's educational policy, has failed in practice to plan and organise activities related to the education of CMBs, despite the growing scale of migration. The Ministry did not collect, monitor or analyse any data concerning such pupils, although it had at its disposal data stored in the Educational Information System (SIO) database. What is more, the Ministry 
failed to collect data on the number of pupils with Polish citizenship returning to the country, hence the scale of this phenomenon is unknown. The Ministry is ignorant of the effectiveness of education of these students because it did not undertake supervisory activities over the organisation and conditions of their education. In particular, the performance of pedagogical supervision by school superintendents was not monitored or evaluated.

The only positive exception was the realisation of the public task "Supporting educational initiatives in a school multicultural environment" implemented since 2015. The state budget allocated 340 million PLN in 2015-2019 (until 29 November) for expenses related to additional support for the education of children of Polish citizens returning to the country and children of foreigners.

The Ministry failed to analyse the needs for methodological counselling and training of in-service teachers working with CMBs. Despite the growing number of schools for CMBs (from 1,571 to 7,318 in the period 2009-2019) and teachers involved in this process, school principals did not perceive the ever-increasing needs in this respect either. The majority of principals ( 20 schools) did not provide support to teachers in their professional development in this area.

Meanwhile, surveyed teachers indicated that the basic problem in their work with CMBs is communication (44\% of indications). Differences in the level of Polish language proficiency among students who use different languages on a daily basis often make it impossible to conduct classes. Another problem is the lack of textbooks for learning Polish as a foreign language and adequate teaching materials, as well as poor support for teachers by schools (7\%). Curriculum differences resulting from studying in other educational systems, especially when students in a given section come from different countries, are also a problem $(7 \%)$. According to teachers, pupils face adaptation and integration problems $(6 \%)$, and contact with pupils' parents is difficult or non-existent $(6 \%)$. These pupils have a low motivation to learn, being unwilling to complete the tasks assigned to them (5\%). Only $4 \%$ of teachers declared that they did not notice any problems when working with foreign students, and considered these children to be more reliable in fulfilling their school tasks than Polish students. More than half of the schools did not undertake any measures at all to integrate foreign students that would respond to their specific cultural needs.

All these irregularities, in the opinion of the SAO, testify to the lack of effective supervision of education of foreign pupils exercised by school principals. The principals tend to ignore the evaluation of important elements of the educational process such as: verifying and assessing educational achievements of students, modification of curricula to their needs, monitoring the progress of students, the effectiveness of psychological and pedagogical support provided to students or cultural integration (NIK 2020). 


\section{CONCLUSIONS AND PEDAGOGICAL IMPLICATIONS}

The Polish migrant integration policy, both at the central and local levels, is at an early stage of development. No coherent and long-term strategy for migrant integration with clearly formulated political and legislative goals has been developed so far (Matusz-Protasiewicz 2014). The related issues have not become the subject of public debate, and there have been no broader efforts to develop a concept of integration (Łodzinski, Grzymała-Kazłowska 2011: 39). Even in the face of the current migration crisis, there is no well-thought-out reflection on the integration of migrants (Ośrodek Badań nad Migracjami 2015). Currently, however, the development of such a concept is becoming necessary due to the possibility of receiving a much larger number of migrants, including refugees, than before.

As observed by Rajca (2015: 197-198), the integration of migrants from the Middle East and North Africa into Polish society can be particularly challenging. Ethnically homogenous Poland is characterised by a low degree of acceptance of this group of migrants and general reluctance for multiculturalism in social life, accompanied by the negative attitude of Poles towards Muslims. Potential migrants from the current wave of migration will not be as familiar with the Polish language, laws and customs as migrants to France or the United Kingdom from former colonies. Besides, Poland will probably be treated as a transit country. For these reasons, potential migrants will probably be less inclined to adopt our system of values. The draft regulation of the Council of Ministers on the relocation of foreigners did not envisage any additional integration measures beyond those already in place. It can be predicted with high probability that the influx of a larger number of migrants to Poland will cause similar problems to those encountered in other European countries in the first half of the 1990s, or even more challenging due to living conditions worse than in the West, lack of housing, difficulties in the labour market, limited integration activities and unfavourable attitudes of the society.

Solutions proposed at the European level have become a model for creating integration activities in Poland. The government adopted the definition of integration as a bilateral process proposed by the European Commission. The policy and practice of integration in Poland are strongly influenced by European funds, but also by the attitudes of the Polish society and the nature of migration to Poland. Integration activities are mainly carried out by non-governmental organisations, independently or in cooperation with public entities, mainly thanks to EU funds. The experience gained will undoubtedly contribute to the development of more comprehensive policies and concepts for the integration of migrants (Rajca 2015: 197). 
It should be emphasised that together with elementary subsistence issues, such as housing and employment, language and education remain considerable challenges. Despite slight progress in education in recent years, schools do not always comply with existing legal regulations on the provision of language education and the Ministry of Education is neither supportive nor truly interested in this matter, as evidenced in the Supreme Audit Office's reports (NIK $2015,2020)$. What comes to the fore is the insufficient qualifications of teachers and their preparation to teach in multilingual classes and lack of institutional and methodological support. There is a burning need for integrated, large-scale actions preparing for language-sensitive teaching, offering tangible support for schools and teachers, as well as organisations teaching the Polish language to adults. It is also essential to undertake educational activities aimed at raising cultural awareness and changing xenophobic attitudes of a large part of Polish society to foster cultural adaptation. Teachers and school authorities should also take a reflective approach and revisit their oftentimes non-empathic attitudes centred on a complete adaptation of migrants to the host country and orient them towards migrants' needs. According to the literature and legislation reviewed, very little attention or care is given to preserving the cultural and linguistic heritage of migrants or to promoting their multilingualism and seeing diversity as an asset rather than a disadvantage. A promising example of such an initiative is the MaMLiSE project currently carried out within the Erasmus+ programme, which aims to develop comprehensive, open-access tools to support teachers, students and parents.

\section{REFERENCES}

Baranowska, G. (2014). Legal regulations on national and ethnic minorities in Poland. Przeglą Zachodni, 2, 35-48.

Common European framework of reference for languages: Learning, teaching, assessment (2001). Cambridge: CUP / Strasburg: Council of Europe. https:/ / rm.coe.int/16802fc1bf [access: 31.03.2021].

FCNM Opinion on Poland (2003). Advisory Committee on the Framework Convention for the Protection of National Minorities Opinion on Poland 2003, ACFC/INF/OP/I(2004)005, Strasbourg, 27 November. https://www.refworld.org/pdfid/447ee05f4.pdf [access: 12.02.2020].

GUS (2011). Wyniki narodowego spisu powszechnego ludności i mieszkań $2002 \mathrm{w}$ zakresie deklarowanej narodowości oraz języka używanego w domu. https://stat.gov.pl/cps/rde/ xbcr/gus/LUD_ludnosc_stan_str_dem_spo_NSP2011.pdf [access: 10.12.2020].

Hut, P. (2002). Warunki życia i proces adaptacji repatriantów w Polsce w latach 1992-2011. Warszawa: Aspra-JR.

Kirpsza, A. (2012). Status prawny mniejszości narodowych i etnicznych w Polsce w świetle standardów Rady Europy. In: J. Jaskiemia (ed.), Efektywność europejskiego systemu ochrony praw człowieka (pp. 743-762). Torun: Wydawnictwo Adam Marszałek. 
Komorowska, H. (2017). Ksztatcenie językowe w Polsce. 60 lat czasopisma "Języki Obce w Szkole". Warszawa: Fundacja Rozwoju Systemu Edukacji.

Konstytucja RP (1997). Konstytucja Rzeczypospolitej Polskiej z dnia 2 kwietnia 1997 r. https:/ / www.sejm.gov.pl/prawo/konst/polski/kon1.htm [access: 15.11.2020].

Konwencja ramowa o ochronie mniejszości narodowych (1995). Strasbourg, February 1, 1995. Journal of Laws 22, 209. http://isap.sejm.gov.pl/isap.nsf/download.xsp/WDU20020220209/O/ D20020209.pdf [access: 12.12.2020].

Kucharczyk, R. (2016). Kontekst nauczania języków obcych w Polsce - glottodydaktyczne implikacje dla drugich języków obcych. Linguodidactica, 20, 195-212.

Kutyła, W. (2014). Wystapienia pokontrolne. Realizacja Rządowego Programu Wspótpracy z Polonia i Polakami za granicą. www.nik.gov.pl/kontrole.wyniki-kontroli-nik [access: 16.02.2021].

Lesińska, M. (2010). Polityka integracyjna. In: A. Górny / I. Grabowska-Lusińska / M. Lesińska / M. Okólski (eds.), Transformacja nieoczywista. Polska jako kraj imigracji (pp. 102-107). Warszawa: Wydawnictwo Uniwersytetu Warszawskiego.

Łodzinski, S. / Grzymała-Kazłowska, A. (2011). Koncepcje, badania i praktyki integracji imigrantów. Doświadczenia polskie w europejskim kontekście. Studia Migracyjne - Przeglad Polonijny, 37, 2 (140), 11-39.

Łodzinski, S. / Ząbek, M. (2010). Perspektywy integracji uchodźców w społeczeństwie polskim. Wyzwania normalnego życia. Ziemia obiecana czy przystanek w drodze? Biuletyn RPO - Materiaty, 70, 224-256.

Matusz-Protasiewicz, P. (2014). Wielopoziomowe zarządzanie migracjami. Rola Europejskiego Funduszu na rzecz Integracji Obywateli Państw Trzecich w ksztattowaniu polityki integracyjnej w Polsce. Wrocław: Uniwersytet Wrocławski.

MIPEX (2015). https:/ / www.mipex.eu/sites/default/files/downloads/files/mipex-2015-book-a5. pdf [access: 16.12.2020].

MIPEX (2020). https:/ / www.mipex.eu/poland [access: 20.03.2021].

Mostowik, P. / Żukowski, W. (2001). Ustawa o jezzyku polskim. Komentarz. Warszawa: Wydawnictwo Prawnicze LexisNexis.

NIK (2015). NIK o systemie pomocy społecznej dla uchodźców - informacje szczegótowe. https:/ / www. nik.gov.pl/plik/id,10216,vp,12539.pdf [access: 16.12.2020].

NIK (2020). Kształcenie dzieci rodziców powracających do kraju oraz dzieci cudzoziemców. https: / www. nik.gov.pl/plik/id,22685,vp,25384.pdf [access: 30.03.2021].

Ośrodek Badań nad Migracjami (2015). Kryzys i co dalej? Biuletyn Migracyjny, 53, 1-13. http:// www.biuletynmigracyjny.uw.edu.pl [access: 30.11.2020].

Pawlak, M. (2013). Imitacja przy tworzeniu polskiej polityki integracji cudzoziemców. Studia Migracyjne - Przegląd Polonijny, 39 (3), 97-121.

Piotrowski, T. (2011). Bezpieczeństwo językowe w dobie ponowoczesnej. In: T. Malczyk (ed.), Interdyscyplinarne znaczenie bezpieczeństwa, vol. 2 (pp. 39-41). Nysa: Oficyna Wydawnicza PWSZ w Nysie.

Pisarek, W. (2007). Polityka językowa Rzeczypospolitej Polskiej, państwa członkowskiego Unii Europejskiej. Strona Internetowa Rady Jezzyka Polskiego. https:/ /rjp.pan.pl/index.php?option=com_content\& view $=$ article\&id $=1382 \& I t e m i d=50$ [access: 15.11 .2020 ].

Polityka migracyjna Polski - diagnoza stanu wyjściowego (2020). 15 December, 2020. Departament Analiz i Polityki Migracyjnej MSWiA. https:/ / www.gov.pl/attachment/2a65e5d4-52c5-40acada9-3b3f988f86b9 [access: 14.11.2020].

Polityka migracyjna Polski - stan obecny i postulowane działania (2012). Document approved by the Council of Ministers on 31 July, 2012. Departament Polityki Migracyjnej MSW. https://emn. 
gov.pl/download/75/12409/Polityka_migracyjna_Polski_stan_obecny_i_postulowane_dzialania.pdf [access: 30.11.2020].

Polska polityka integracji cudzoziemców - założenia i wytyczne. Projekt (2013). Warszawa, 23 September, 2013. Departament Polityki Migracyjnej MSW. https://archiwum.mrips.gov.pl/download/ gfx/mpips/pl/defaultopisy/8305/1/1/Polska\%20polityka\%20integracji\%20cudzoziemcow\%20-\%20zalozenia\%20i\%20wytyczne.doc [access: 30.11.2020].

Poszytek, P. / Gorzelak, M. / Dakowicz-Nawrocka, A. / Płoszajska, G. / Kujawa, B. / Dłużniewski, S. / Płoszaj, T. / Trzcińska, B. / Grabowska, L. (2005). Country report. Language education in Poland. Warszawa: Ministerstwo Edukacji Narodowej.

Prezydent.pl. https://www.prezydent.pl/prawo/ustawy/zawetowane/art,2,prezydent-zawetowal-trzy-ustawy.html

Rajca, L. (2015). Integracja imigrantów w Polsce w dobie kryzysu migracyjno-uchodźczego. Chorzowskie Studia Polityczne, 10, 183-202.

Raport Eurydice / Komisja Europejska (2017). Kluczowe dane o nauczaniu języków w szkołach w Europie. Warszawa: Fundacja Rozwoju Systemu Edukacji. https:/ / eurydice.org.pl/wp-content/ uploads/2017/12/KDL_PL_2017.pdf [access: 28.11.2020].

Romanowski, P. (2020). The Polish linguistic map: An overview of minority languages in the education system. In: P. Romanowski / M. Guardado (eds.), The many faces of multilingualism: Language status, learning and use across contexts (pp.11-24). Berlin / Boston: De Gruyter Mouton.

Smolik, M. / Poszytek P. (2017). Podstawa programowa kształcenia ogólnego w zakresie języka obcego nowożytnego w wychowaniu przedszkolnym i ośmioletniej szkole podstawowej słowo komentarza. Jezzyki Obce w Szkole, 1, 70-81.

Statistics Poland (2020). Statistics Poland. Education in the 2019/2020 school year. http:/ / stat.gov.pl/ obszary_tematyczne/edukacja/ [access: 10.04.2021].

Ustawa o języku polskim. (2018). Obwieszczenie Marszałka Sejmu Rzeczypospolitej Polskiej z dnia 13 kwietnia 2018 r. w sprawie ogłoszenia jednolitego tekstu ustawy o języku polskim. Journal of Laws 2018, item 931. http:/ / isap.sejm.gov.pl/isap.nsf/download.xsp/WDU20180000931/T/ D20180931L.pdf [access: 10.12.2020].

Ustawa o mniejszościach narodowych i etnicznych oraz o języku regionalnym z dnia 6 stycznia 2005 r. (2017). Obwieszczenie Marszałka Sejmu Rzeczypospolitej Polskiej z dnia 5 kwietnia 2017 r. Journal of Laws 2017, item 823. http:/ /isap.sejm.gov.pl/isap.nsf/download.xsp/ WDU20170000823/O/D20170823.pdf [access: 12.12.2020].

Ustawa o systemie oświaty z dnia 7 września 1991 r. (1991). Journal of Laws 1991 no 95, item 425. https:/ / isap.sejm.gov.pl/isap.nsf/download.xsp/WDU19910950425/O/D19910425.pdf [access: 12.12.2020].

Wąsikiewicz-Firlej, E. / Szczepaniak-Kozak, A. / Lankiewicz, H. (in press). Doświadczenie pobytu w Polsce w narracjach zagranicznych studentów. Warszawa: Fundacja Rozwoju Systemu Edukacji.

Received: 07.05.2021; revised: 24.10 .2021

EMILIA WĄSIKIEWICZ-FIRLEJ

Uniwersytet im. Adama Mickiewicza w Poznaniu

emiliawf@amu.edu.pl

ORCID: 0000-0003-4457-9715 
